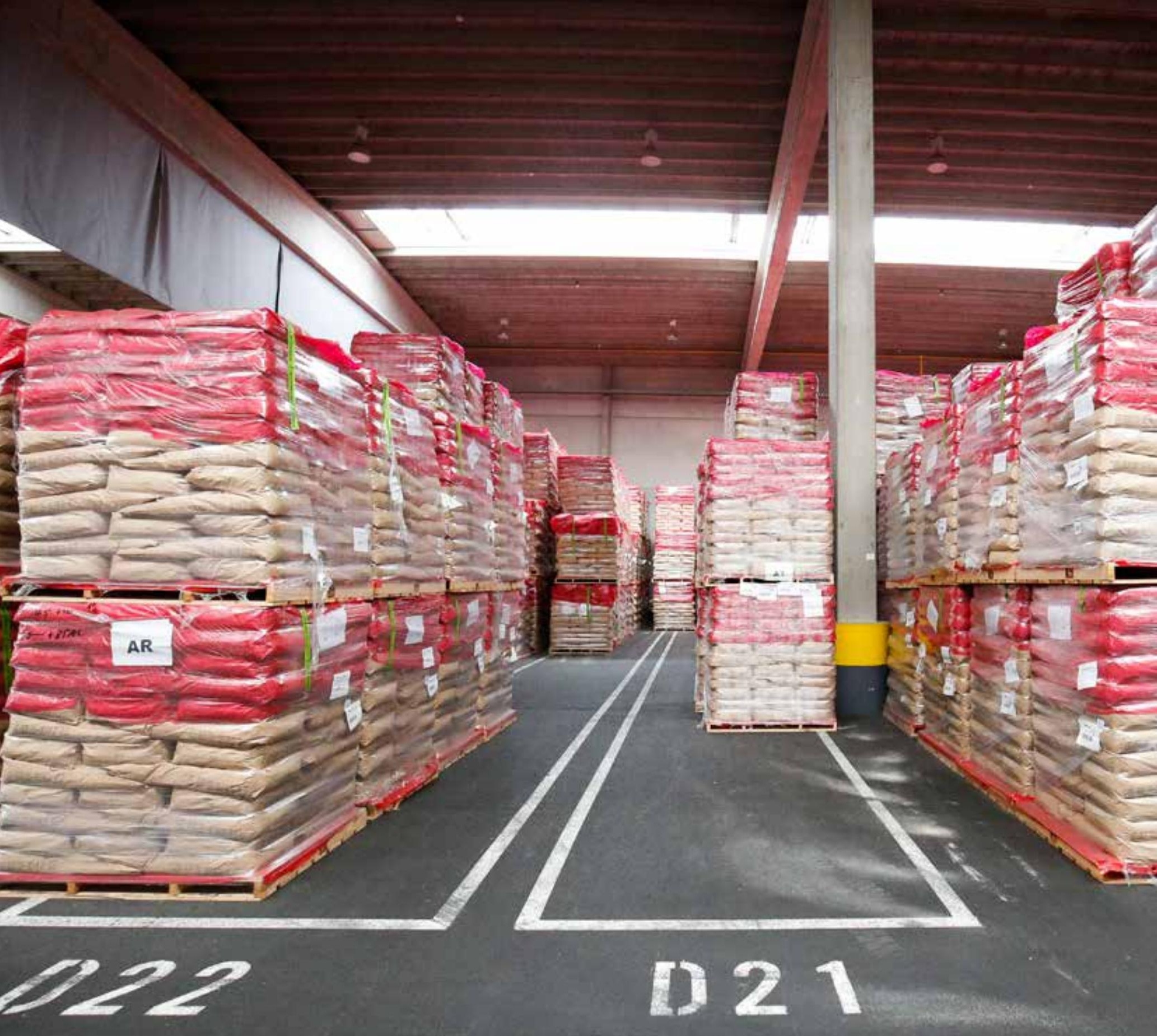

\title{
Effects of selling public intervention stocks of skimmed milk powder
}





\section{Effects of selling public intervention stocks of skimmed milk powder}

Roel J ongeneel, Huib Silvis, David Verhoog, Co Daatselaar

This study was carried out by Wageningen Economic Research and was commissioned and financed by the Dutch Ministry of Agriculture, Nature and Food Quality within the context of the 'Agricultural economics, markets and trade research theme of the Policy Support Research (project number BO-43-014.01-010)

Wageningen Economic Research

Wageningen, April 2018

REPORT

2018-046

ISBN 978-94-6343-857-5 
J ongeneel, R.A., H.J. Silvis, A.D. Verhoog, C.H.G. Daatselaar, 2018. Effects of selling public intervention stocks of skimmed milk powder. Wageningen, Wageningen Economic Research, Report 2018-046. 30 pp.; 7 fig.; 8 tab.; 11 ref.

At the request of the Dutch Ministry of Agriculture, Nature and Food Quality, this report analyses the potential market impacts and budgetary effects of different strategies of selling EU public intervention stocks of skimmed milk powder (SMP). A gradual phasing out of the EU's SMP stocks over a two-year period is likely to have a negative impact on the EU'S SMP prices. The use of alternative market outlets reduces the negative price impacts on the regular SMP market, but implies that a significant loss in sales value of SMP stocks has to be accepted. When the stocked SMP ages, at a certain moment there may be no other option than the use of alternative channels to destock and an increasing budget expenditure will then be unavoidable.

Key words: price support, skimmed milk powder, EU intervention stocks, sales strategies

This report can be downloaded for free at https://doi.org/10.18174/446329 or at www. wur. eu/economic-research (under Wageningen Economic Research publications).

(C) 2018 Wageningen Economic Research

P.O. Box 29703, 2502 LS The Hague, The Netherlands, T +31 (0)7033583 30,

E communications.ssg@wur.nl, http://www.wur.eu/economic-research. Wageningen Economic Research is part of Wageningen University \& Research.

\section{(cc) BY-NC}

For its reports, Wageningen Economic Research utilises a Creative Commons Attributions 3.0 Netherlands license.

(C) Wageningen Economic Research, part of Stichting Wageningen Research, 2018

The user may reproduce, distribute and share this work and make derivative works from it. Material by third parties which is used in the work and which are subject to intellectual property rights may not be used without prior permission from the relevant third party. The user must attribute the work by stating the name indicated by the author or licensor but may not do this in such a way as to create the impression that the author/licensor endorses the use of the work or the work of the user. The user may not use the work for commercial purposes.

Wageningen Economic Research accepts no liability for any damage resulting from the use of the results of this study or the application of the advice contained in it.

Wageningen Economic Research is ISO 9001:2008 certified.

Wageningen Economic Research Report 2018-046 | Project code 2282200389

Cover photo: Belga Photo/Hollandse Hoogte 


\section{Contents}

$\begin{array}{ll}\text { Preface } & 5\end{array}$

$\begin{array}{ll}\text { Summary } & 6\end{array}$

$\begin{array}{lll}\text { S.1 Key findings } & 6\end{array}$

$\begin{array}{lll}\text { S.2 Other findings } & 7\end{array}$

$\begin{array}{lll}\text { S.3 Justification } & 7\end{array}$

\begin{tabular}{l|l}
1 & Introduction
\end{tabular}

1.1 Background $\quad 8$

$\begin{array}{lll}1.2 & \text { Research objective } & 9\end{array}$

$\begin{array}{lll}1.3 & \text { Outline of the report } & 9\end{array}$

$2 \quad$ Research methods $\quad 10$

$\begin{array}{lll}2.1 & \text { Introduction } & 10\end{array}$

$\begin{array}{lll}2.2 & \text { Quantitative analysis } & 10\end{array}$

$\begin{array}{lll}2.3 & \text { Qualitative analysis } & 13\end{array}$

$3 \quad$ EU SMP intervention and world SMP market $\quad 14$

3.1 EU SMP intervention $\quad 14$

$\begin{array}{lll}3.2 & \text { World SMP market } & 15\end{array}$

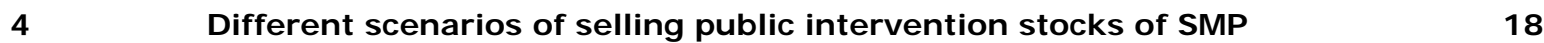

$\begin{array}{lll}4.1 & \text { Destocking strategies } & 18\end{array}$

$\begin{array}{lll}4.2 & \text { Alternative outlets } & 19\end{array}$

$5 \quad$ Market impacts and budgetary effects $\quad 21$

$\begin{array}{lll}5.1 & \text { Results } & 21\end{array}$

$\begin{array}{lll}5.2 & \text { Implications } & 22\end{array}$

6 Discussion and concluding remarks $\quad 24$

$\begin{array}{ll}\text { References and websites } & 26\end{array}$

$\begin{array}{lll}\text { Appendix } 1 & \text { Feed protein market in the EU } & 27\end{array}$ 



\section{Preface}

The Dutch Ministry of Agriculture, Nature and Food Quality has asked Wageningen Economic Research to analyse the potential market impacts and budgetary effects of different strategies of selling EU public intervention stocks of skimmed milk powder.

On behalf of the Ministry Niek Schelling and Frits Vink acted as client of the study. Roel J ongeneel acted as leader of the research.

The report has been reviewed by Coen van Wagenberg, Senior Scientist, and Krijn Poppe, Strategy Manager Agriculture and Food of Wageningen Economic Research.

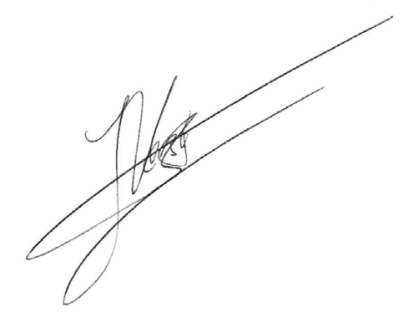

Prof.dr.ir. J.G.A.J. (J ack) van der Vorst General Director Social Sciences Group (SSG)

Wageningen University \& Research 


\section{Summary}

\section{S.1 Key findings}

The main EU destocking strategies for skimmed milk powder (SMP) analysed in this scenario study differ with respect to the market outlets:

1. A fixed sales pattern of monthly sales of 20 thousand tonnes during a period of 1.5 years.

2. A sales for non-human consumption strategy; this implies denaturation of the SMP so that it is no longer suitable for human consumption and that it will be sold as a protein source for animal feed.

3. A mixed sales strategy, where the SMP stock is split up into two categories, taking into account the shelf life. The first category may be sold as fresh product (age less than 1.5 year), whereas the second category has a lower market attractiveness (age more than 1.5 year), which will need a price discount.

In all scenarios, complete destocking is assumed to take place in 2018 and 2019. In scenario 1, prices of SMP decrease by $5.3 \%$ (from $€ 1,350$ to $€ 1,278.80$ per tonne) in 2018 and $3.6 \%$ in 2019 . In scenario 3 , the market price decline is $2.4 \%$ for each of the two years. Scenario 2 , which involves channelling the destocked SMP fully to alternative markets, leads to a marginal negative price impact, due to a limited substitution or spill-over effect from the alternative market to the regular SMP market.

The public budget or sales revenues from stock sales are highest in scenario 1 and lowest in scenario 2, and those in scenario 3 are in between. Revenue per tonne of SMP stocks sold at alternative markets (about $€ 495$ to $€ 1,000$ per tonne, with prices varying by outlet and due to the quantity sold on the alternative market outlets) is generally lower than stocks sold at the regular SMP market $(€ 1,350$, even when taking into account a $€ 500 /$ tonne discount effect because of its lower market attractiveness.

Table S.1 Simulation results of EU destocking scenarios on SMP and other markets and government revenues and budget costs

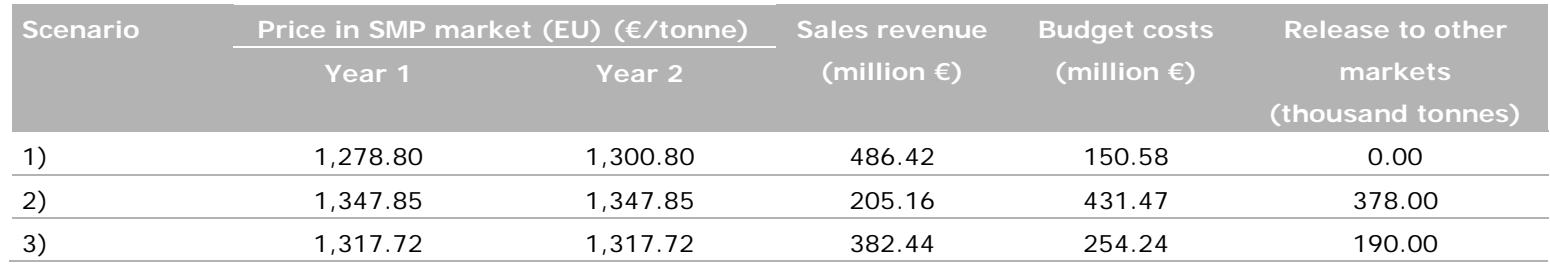

Source: Own calculations.

The strongest price declines of SMP are observed in the EU market, and the next largest on the markets of competing exporters (Figure S.1). These impacts follow from the assumed imperfect price transmission. As a consequence, the impact on third country markets is less strong than in the EU. However, as the 'Major importers' and 'Rest of the World' are the main demanding regions, in scenario 1 the EU's destocking strategy is likely to lead to a more intensive competition between the world's key SMP exporters than is the case in scenario 2 (no impact) and scenario 3 (more limited impact).

The public budget expenditure associated with stockpiling and stock sales differs over scenarios, with scenario 1 having the lowest budget expenditure $(€ 150 \mathrm{~m}$, taking into account expenditure of both periods). The expenditures in case of scenario 2 are more than double that of scenario 1 , and the expenditures in scenario 3 are in between. The main contributing factor to the differences in EU budget expenditures are the differences in sales revenues. The storage costs and interest costs (playing a minor role) are more or less fixed over all scenarios because they mainly depend on the historical buying-in pattern, while the destocking strategies all lead to a complete elimination of the stocks in a period of 2 years and all scenarios assume a gradual phasing out of the SMP stocks. 


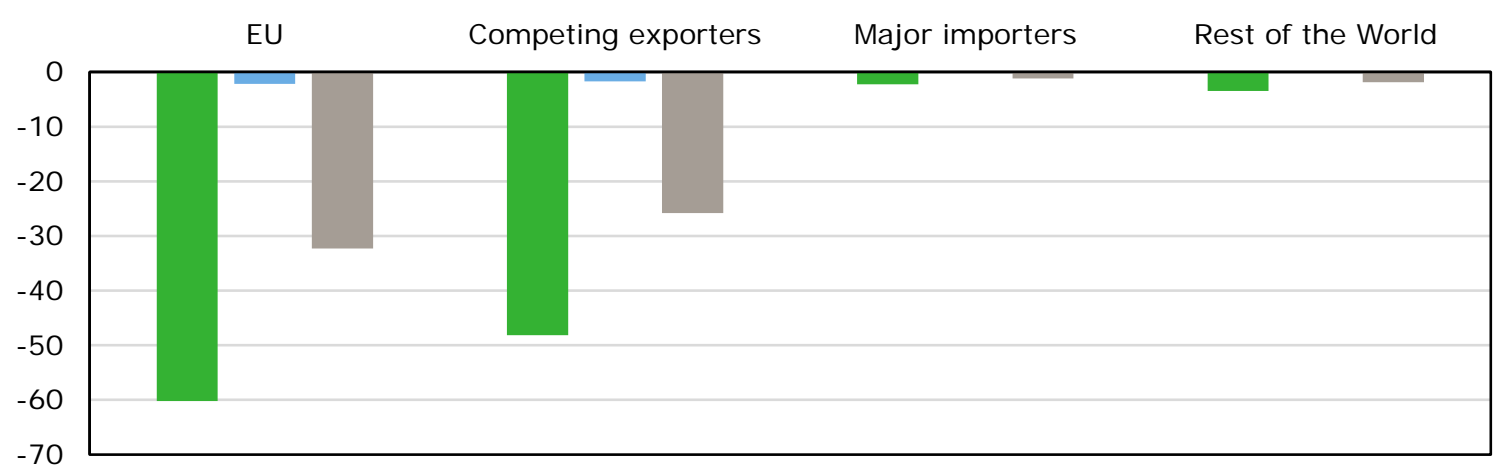

mscen1 $\square$ scen2 $\square$ scen3

Figure S.1 Impact on SMP price (changes in $€ /$ tonne) of different destocking strategies

\section{S.2 Other findings}

In addition to the three scenarios a fourth scenario has been studied. This scenario consists of sales by a tendering system, where there are separate tenders for stocks by month of intake (period 1 March 2015 - 31 September 2017). This allows taking into account the age impact of the product. Due to a lack of reliable information (price discount-age relationship), this scenario could only be analysed in a qualitative way. Its market impacts could have similarities with the ones of scenarios 2 and 3 , but the stock sales revenues are likely to be larger (price discrimination).

A sensitivity analysis was done by halving the supply and demand elasticities (from 0.5 to 0.25 ). In case of scenario 1, the maximum price decline observed for SMP was $10 \%$. One could think of this an approximation of the upper bound of the negative price effect of a gradual phasing out of EU SMP stocks. When viewed in the context of the large price fluctuations that have been observed, a $10 \%$ price decline due to destocking is still relatively small. The negative impact of a gradual destocking strategy on the calculated equivalent milk price is likely to be limited $(<5 \%)$. Price changes currently observed in the SMP market can only to a limited extent be explained by the changes in stock levels but are also driven by other factors, including changes in market and price expectations (e.g. strategic behaviour).

\section{S.3 Justification}

The Dutch Ministry of Agriculture, Nature and Food Quality has asked Wageningen Economic Research to analyse the potential market impacts and budgetary effects of different strategies of selling EU public intervention stocks of SMP. In recent years the European Union has accumulated large public intervention stocks of SMP. The lack of clarity about what is going to happen with the SMP stocks is putting pressure on the price of SMP and hindering its recovery. Moreover, milk production growth is expected in 2018 as compared to 2017 and 2016, which may increase the supply of fresh SMP, while the older intervention stocks are losing attractiveness for buyers. All this creates an interest in which sales strategies could be followed and what their impacts will be.

For the quantitative analysis of releasing strategies of the EU's public SMP stocks an equilibrium displacement modelling framework (EDM) has been applied. The EDM for this study distinguishes four countries or regions involved in the production and consumption of SMP. These are arranged in such a way that the whole world is covered: EU, major exporters, major importers and rest of the world. For these regions demand and supply equations are defined, while for the EU and the US also the public intervention stocks have been included. The elasticities used are synthetic estimates taking into account information based on Bartova et al. (2009) (AGMEMOD model), available literature on price transmission in dairy product markets, and own estimates about the impact of stocktaking on the market. For modelling alternative market outlets, information from involved experts has been used. 


\section{$1 \quad$ Introduction}

\section{$1.1 \quad$ Background}

In recent years the European Union (EU) has accumulated large public intervention stocks of skimmed milk powder (SMP) (Figure 1.1). The earlier part (2015-2016) is related to the abolition of the milk quota system and to the Russian ban. The more recent intervention (2017) has been due to extremely low SMP prices while the milk price for farmers was not abnormal, thanks to very high butter prices. Then intervention followed more from the structure of the trigger mechanisms and less from the need to support the farm-gate milk price. Note that intervention is related to a safety net provision, which is in general quite low and seldom triggered.

\section{Public SMP Intervention scheme (2016-2017) Buying-in quantity at fixed price}

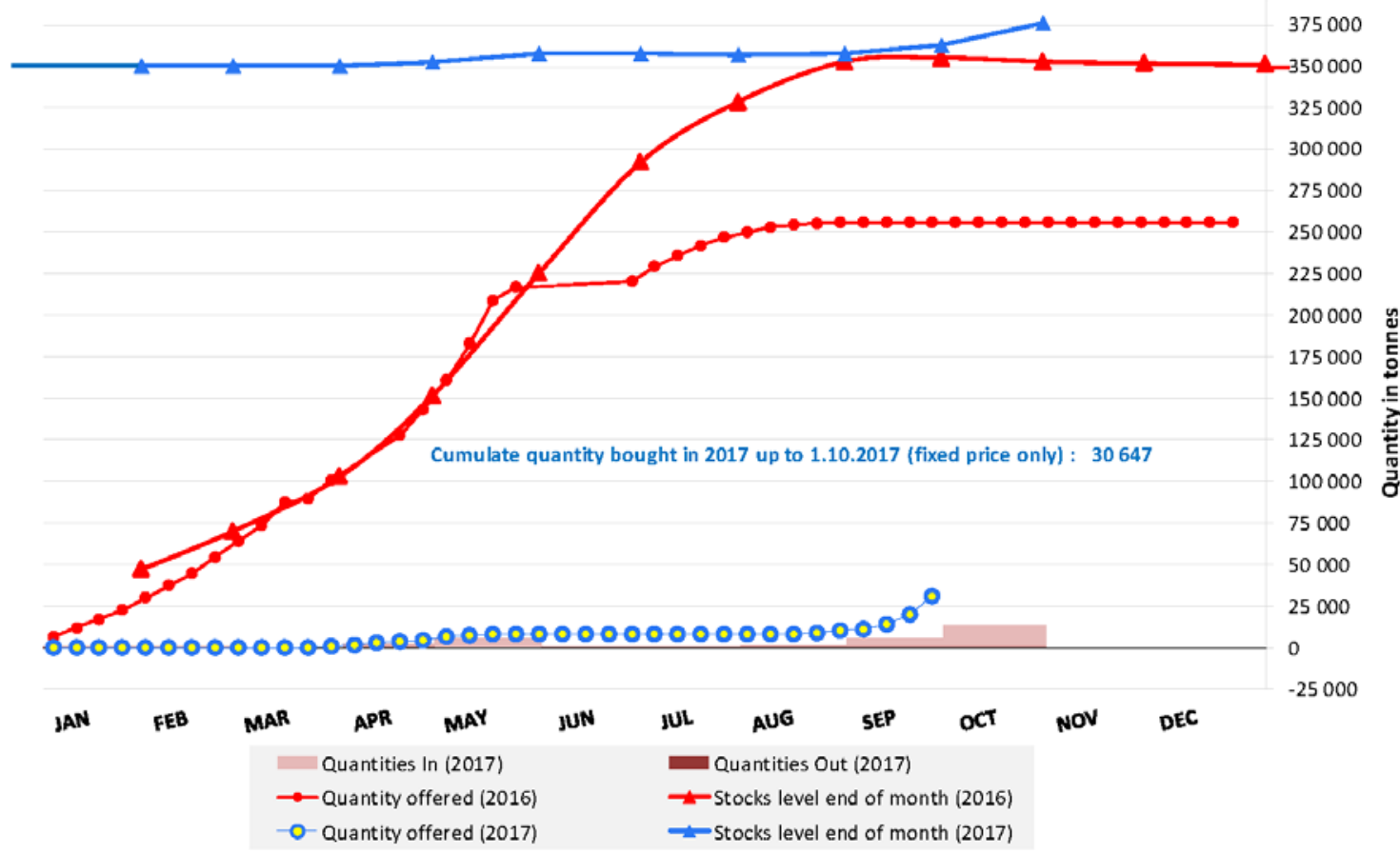

Figure 1.1 Cumulative quantity of the Public SMP Intervention scheme (2016-2017) Source: European Commission.

Now the stocks have grown to a significant volume (385,000 tonnes) and are hanging over the market. Due to the high stock levels, the European Commission has implemented a temporary change to the buying-in ceiling for SMP, reducing it to zero for the 2018 window (1 March - 31 September). This will limit (or avoid) any further stock accumulation. To reduce the stocks, the Commission began to offer SMP intervention stock up for sale from December 2016, via a tendering process. More than 15 tenders for the sale of intervention stocks have been made, of which less than half have been successful. According to the most recent tender on 20 February 2018, only 4,337 tonnes was sold at a minimum price of $€ 1,110 /$ tonne (source: MMO).

The lack of clarity about what is going to happen with the SMP stocks is having a negative impact on the worldwide SMP price and hindering its recovery. Moreover, milk production growth is expected in 2018 as compared to 2017 and 2016, which is likely to increase the supply of fresh SMP, while the 
older intervention stocks are losing attractiveness for buyers. All this creates an interest in which sales strategies could be followed and what their impacts will be.

\subsection{Research objective}

The objective of this study is to analyse the market and budgetary impacts of different destocking strategies with respect to the EU's public intervention stocks of SMP. All strategies include complete destocking in 2018 and 2019, but they differ with respect to the market outlets. The following scenarios have been developed, which, in a stylised way, represent four potential destocking strategies:

- A fixed pattern of monthly sales of 20 thousand tonnes during a period of 1.5 years.

- A sales strategy for non-human consumption. After denaturation the SMP is no longer suitable for human consumption and it will then serve as a protein source for animal feed.

- A mixed sales strategy, where the SMP stock is split up into two categories, taking into account the shelf life. The first category may be sold as high quality product (age less than 1.5 year), whereas the second category has a lower market attractiveness (age more than 1.5 year), which will need a price discount.

- Sales by a tendering system, where there are separate tenders for stocks by month of intake (period 1 March 2015 - 31 September 2017). This strategy allows taking into account the age impact of the product.

\subsection{Outline of the report}

Chapter 2 describes the quantitative and qualitative research methods. In the quantitative analysis the equilibrium displacement modelling framework (EDM) plays a central role. Chapter 3 provides an overview of the public intervention stocks of SMP and the EU and world SMP market. Chapter 4 elaborates the different scenarios for selling the PI stocks of SMP and potential alternative outlets for destocked SMP. Next, the results of the strategies in terms of market impacts and budgetary effects are presented (Chapter 5). The report closes with a discussion and final remarks (Chapter 6 ). 


\section{Research methods}

\subsection{Introduction}

As regards the analysis of the EU dairy sector, including its dairy products markets, Bartova et al. (2009) is one of the most recent available studies, which provides an analysis of the quota abolition. This study used the AGMEMOD partial equilibrium model of EU agriculture. The AGMEMOD model is an up-to-date tool, since it is used for the generation of market outlooks and therefore regularly updated, while it also takes the information from quarterly short-run estimates into account (Salpetra et al., 2017). However, a drawback is that the model has a limited representation of the world market as the focus of this model is on the EU. Another up-to-date model, used by the EU Commission and the OECD, is the AGLINK-COSIMO model, which has full world coverage of the key agricultural product markets, including dairy. However, also this model has limited details with respect to alternative uses of SMP other than human consumption. For studying the problem at hand it might be better to use a more targeted and simplified modelling approach.

Together with Whole Milk Powder (WMP), SMP is an intensively traded dairy product and has a global market. There are a number of studies that analyse price transmission in world dairy markets, both over countries and between different dairy products. From this literature it appears that the price transmission is imperfect and asymmetric. Chavas and Kim (2001), who focused on the US dairy markets and the three dairy products (American cheese, butter and non-fat dry milk) found that there are cointegrating relationships between dairy product prices, which reflects hedonic component pricing, at least in the longer run. But they also provided evidence of significant short-term dynamics that is unrelated to the dynamics of hedonic prices. This suggests that in the short run the price transmission between different dairy products is imperfect. Other studies, focusing on international markets, such as Gould and Villarreal (2002) and Carvalho et al. (2015), concluded that there were no price transmission effects into the United States from international dairy markets. However, Newton (2016) found that US dairy commodity prices for cheddar, butter, and dry milk powders are influenced by the prices of dairy products in international markets. But he also partly confirmed previous studies in showing that US cheddar and butter prices do spread into other dairy markets. For milk powders, Newton found a one-way price relationship, as price shocks in Oceania and the European Union spread to the United States while US price shocks did not spread into those markets and more generally price shocks in US powder prices do not significantly spread into other markets. However, the dairy product markets, and especially the widely traded powders of the EU, Oceania and the US, are increasingly integrated. This is likely to hold to a lesser extent for importing countries and developing countries. Therefore, when analysing market impacts of policy shocks to the SMP market, there is reason to account for imperfect price transmission, though the literature is not very helpful in providing precise information on this.

\subsection{Quantitative analysis}

For the quantitative analysis of releasing strategies of the EU's public SMP stocks, an equilibrium displacement modelling framework (EDM) is applied. EDMs are models in which equations are expressed as the log of differential forms and the (elasticity) parameters linked with exogenous and endogenous variables. EDMs can provide detailed commodity specific results. Usually there is no need to estimate supply and demand functions as these can be calibrated, using elasticity information from other sources (including literature and information from already existing other models). Moreover, they can be well-tailored to the research problem at hand, and as such are more flexible than large sector models. 
The EDM for this study distinguishes four countries or regions involved in the production and consumption of SMP. These are arranged in such a way that the whole world is covered: EU, major exporters, major importers and rest of the world. For these regions demand and supply equations are defined, while for the EU and the US also the public intervention stocks have been included. The elasticities used are synthetic estimates taking into account information based on Bartova et al. (2009) (AGMEMOD model) and literature on price transmission in dairy product markets, and own estimates about the impact of stocktaking on the market.

The impact of SMP stock procurement on the market is illustrated in the left panel of Figure 2.1. The buying in of SMP by the intervention authority creates additional demand in the market $\mathrm{db}$. This additional demand leads to a shift in the market equilibrium of $E_{0}$ to $E_{1}$. Note that the final increase in the volume that is traded, $\Delta q$, is less than the amount of SMP that is procured for intervention. In the case of stock disposal, the opposite movement is expected: stock release will generate additional supply which will have a negative impact on price and a positive impact on the volume that is traded.
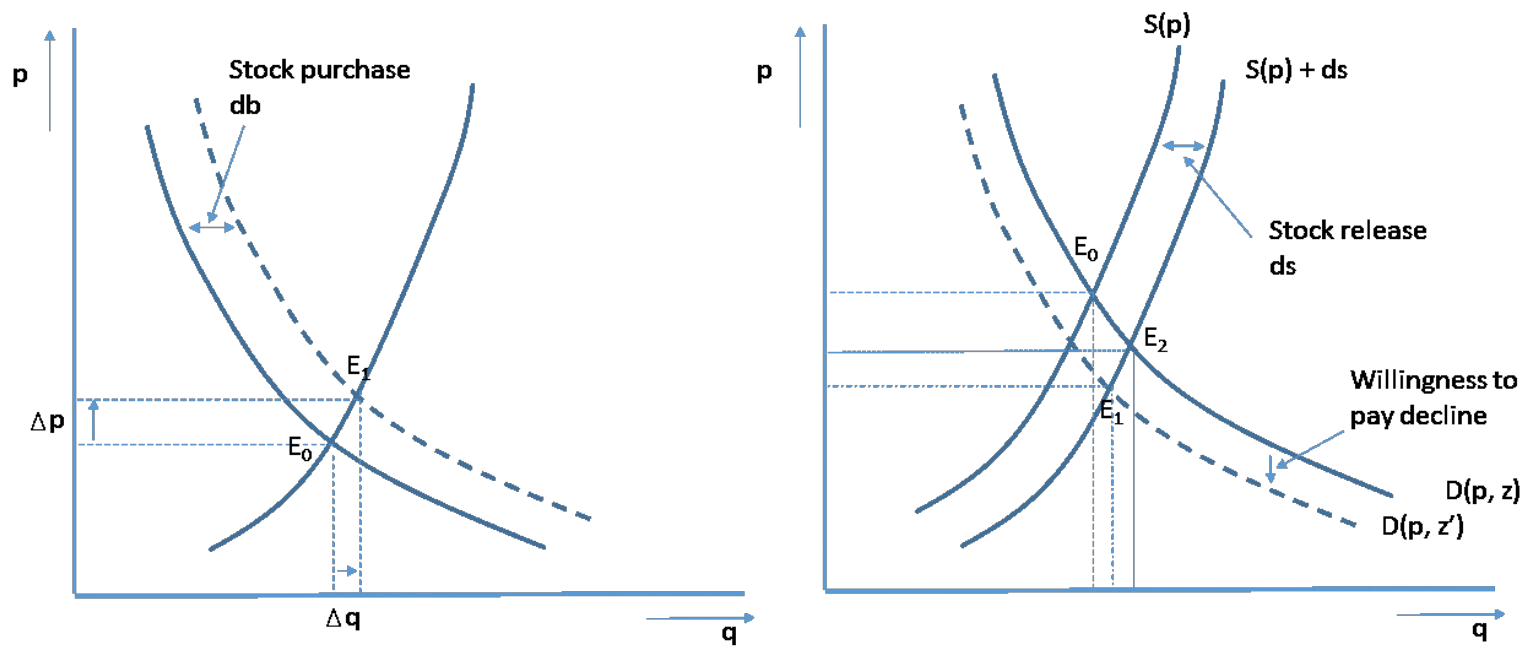

Figure 2.1 SMP stock buying in (left panel) and SMP stock release, quality change and willingness to pay (right panel)

The impact of the release of stocks from intervention on the market is further illustrated in the right panel of Figure 2.1. This operates as an increase in supply by the amount of the stock sales ds. According to observations based upon recent stock sales and signals from the market (interviews with a trader and two other dairy experts) there is a quality issue with SMP stocks. Although SMP wellstored according to EU-requirements may keep its intrinsic quality for many years, the longer SMP is stocked the more its quality, as perceived by the market (buyers), declines. To account for this, a quality variable $z$ is added to characterise the SMP. It is assumed that as destocking will imply that lower quality product becomes available, the average quality of the SMP product in the market will decline, be it in a limited way, since the stock will be always a small part of the total volume of product that is exchanged. In the model, a (perceived) decline in quality will lead to a decline in the willingness to pay of the buyers, or a downward shift of the demand curve (see Figure 2.1, right panel). As a consequence, when a stock release of ds takes place it does not move the market from equilibrium $E_{0}$ to $E_{2}$, as would be the normal case with a positive supply shock. But now, as the buyers become aware that lower quality stock product enters the market, it lowers their willingness to pay (see downward shift of the demand curve from $D(p, z)$ to $D\left(p, z^{\prime}\right)$, where $z$ is the quality variable and $z^{\prime}<z$, indicating a lower 'average' product quality. The consequence of the quality effect is that it can lead to induce a larger price reduction in order to have the buyers taking up the full supply, including the amount of de-stocked product ds. 
Since there is evidence from the literature that, especially in the short-term, price transmission between international SMP producers and consumers can be imperfect (when countries are less integrated in world markets or more sheltered from world market price signals by domestic policies) an allowance is made for this in the analytical tool.

For several reasons, the role of private stocks is not taken into account explicitly. Only limited information about these private stocks is available. Furthermore, their role is likely to accommodate the smoothing of supply throughout the season, as well as normal stocks that SMP processors keep to ensure a smooth running of their facilities. Finally, as far as these stocks are kept for speculative reasons, they might be assumed to be rather low, as it is clear that the public SMP stocks in the EU and the US are hanging over the market. ${ }^{1}$

The accumulation, storage and destocking have budget implications, which are modelled by taking into account the procurement costs of stock acquisition (monthly intake, $b(m)$, times the market price relevant at the moment of intake), $p(m)$, the costs of storage (monthly cost csm times the average monthly stock level $\mathrm{S}(\mathrm{m}))^{2}$, and the revenues obtained from stock sales (monthly sale volume, $\mathrm{s}(\mathrm{m}$ ) times the market sales price $p(m)$ ). Note that the stock level at the end of month $m, S(m)$ is equal to $\mathrm{s}(\mathrm{m}-1)+b(\mathrm{~m})-\mathrm{s}(\mathrm{m})$. The net total budget costs NTC are then given by

$$
N T C=\sum_{m=1}^{M} p(m) \cdot b(m)+0.5 c_{s m} \sum_{m=1}^{M}(S(m)-S(m-1))-\sum_{m=1}^{M} p(m) . s(m)
$$

Given the relatively short time period involved, no time discounting has been applied. More specifically it has been assumed that SMP procurement is taking place at $95 \%$ of the intervention price $(€ 1,698 /$ tonne). The Commission pre-finances this storage cost, with the real economic cost being the interest costs associated with lending the capital needed to buy the stock (an interest rate of $2 \%$ is used). When the stocks are sold depending on their price, there is a value gain or loss. Stocking costs are estimated to be €2.30/tonne per month, and include a compensation for storage costs. There are special costs associated with the stocktaking, including a quality control (sampling). These costs are estimated to be $€ 20 /$ tonne and are applied as a mark-up to the buying in price. The sales price are made scenario dependent, because they are likely to differ in the effective discounts that will be accepted, to get a sufficient uptake in the market.

In the scenarios that will be analysed, destocking or part of the destocking may also involve release in alternative or third markets, which could involve the use for feed. These third markets are modelled by a set of separate demand curves (for example as feed $D_{\text {feed }}$ ( psMP, $_{\text {protein meal }}$ ) in case of SMP denaturation and its subsequent sales into the feed market). Figure 2.2 provides a graphical illustration, where the demand in the alternative SMP market consists of three different groups ( $a, b$, c) that are interested, but have a different willingness to pay.

\footnotetext{
${ }^{1}$ Speculation may have an impact on short-term SMP price formation, but it is not possible to directly capture this in the current analysis.

2 The monthly storage costs include the interest costs for financing the stock purchases.
} 


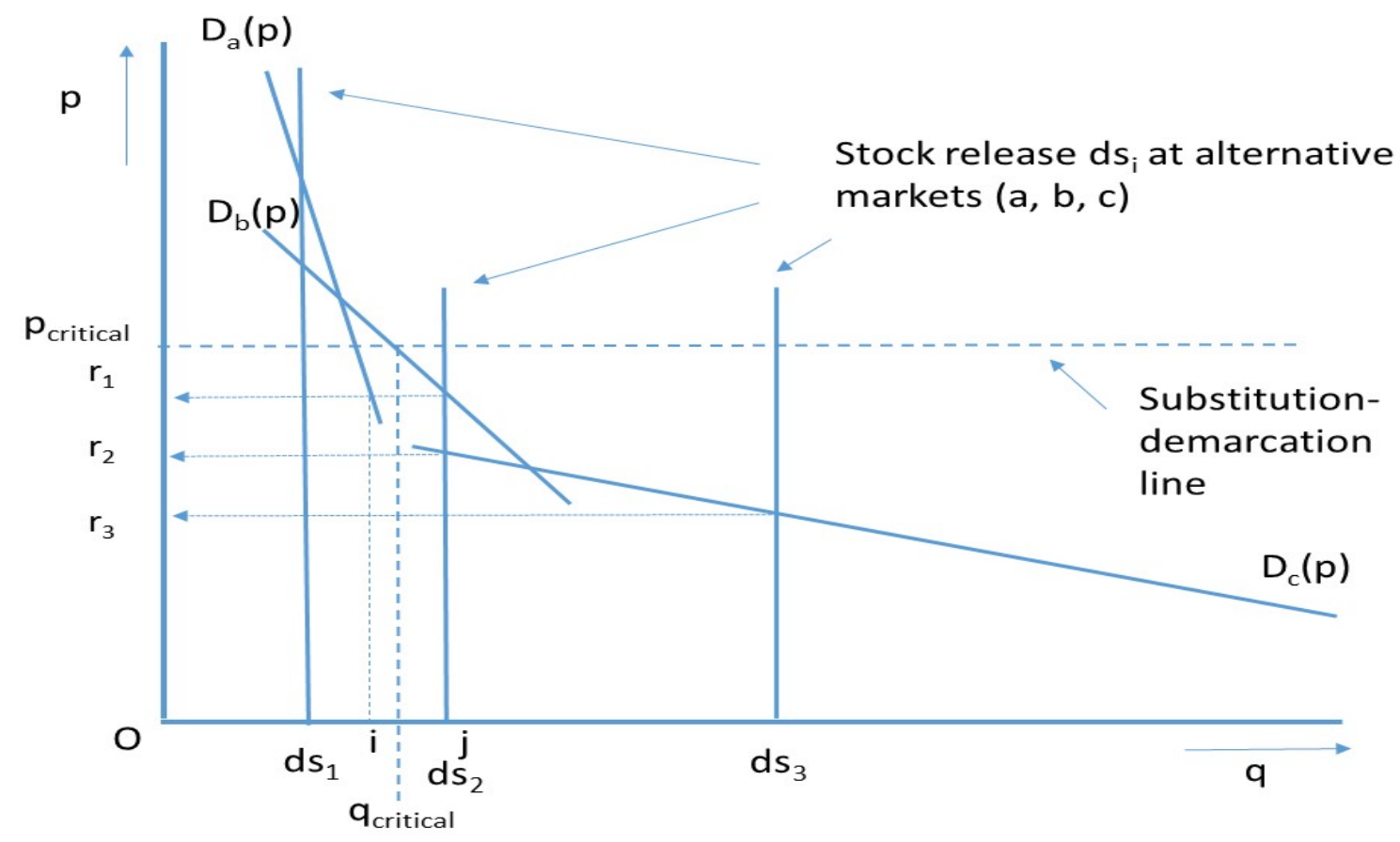

Figure 2.2 SMP disposal at alternative markets

The price the Commission could receive by making SMP sales to the alternative market depends on the amount that will be placed there (e.g. ds $1, d s_{2}, d s_{3}$, and the associated prices (via a tendering procedure) of $r_{1}, r_{2}$, and $r_{3}$ respectively). When the amount that will be released in the alternative SMP market increases, more uses might be exploited at increasingly lower prices. It is assumed that below a certain price ( $p_{\text {critical }}$ ) the SMP will be used for destinations that do not compete at all with the normal SMP market (e.g. destination c). For destinations a (e.g. market for milk replacer used in veal feeds) and part of $b$ there is competition with the normal SMP market. So if $\mathrm{ds}_{1}$ is placed in the alternative market it is likely that this will have some crowding-out effect. However, for every unit of product in excess of $q_{\text {critical }}$ it is assumed that the crowding-out effect will be zero. Product treatment, such as denaturation, may reduce potential spill-over effects to the conventional SMP market. The information needed to recover the demand curve for the alternative market, as well as the role of a crowding-out factor, has been determined using expert information from traders and feed compounders. Note that when $\mathrm{ds}_{2}$ is placed on the alternative market, buyers of two (or multiple) alternative uses may be taking up the product.

\subsection{Qualitative analysis}

The qualitative analysis involves some additional considerations about the scenarios 1,2 and 3 based on the discussions with experts. This enables to take into account aspects that cannot so easily be modelled, and may lead to a qualification of the quantitative results. The qualitative analysis also includes a further assessment of scenario 4 (see details on scenarios in Chapter 4), which could not be directly assessed in a quantitative way, due to lack of reliable information. 


\section{EU SMP intervention and world SMP market}

\subsection{EU SMP intervention}

The objective of the EU's intervention policy is to provide a minimum floor in the market (safety net) during times of low prices. Although the intervention measures concern the procurement of skimmed milk powder and butter, targeting the non-fat and fat solid components of the milk, the primary aim is to support a farm-gate milk price. Table 3.1 provides a schematic overview of the linkage between the 'equivalent' farm-gate milk price (IMPE). ${ }^{3}$ The safety net level for the farm-gate milk price is currently fixed at $€ 21 / 100 \mathrm{~kg}$, which is just supported by the guaranteed intervention price floors (safety net trigger levels) for SMP and butter. The shares of SMP and butter in the valuation of the calculated equivalent milk price is 60 and $40 \%$ respectively.

Table 3.1 Milk price support to producer prices through intervention at the guaranteed intervention prices for SMP and butter

\begin{tabular}{lcc} 
(values in $€ / 100 \mathrm{~kg}$ ) & SMP & Butter \\
\hline Intervention price (safety net trigger levels) & 169.80 & 221.70 \\
\hline Buying in price & 24.00 & 199.53 \\
\hline less Processing margin & 145.80 & 25.57 \\
\hline Raw material value of product & 11.00 & 173.96 \\
\hline divided by Yield factor (kg. of 3.7\% fat milk/1 kg of product) & 20.94 \\
\hline IMPE whole milk, 3.7\% fat, delivered & 63 & 22.649 \\
\hline Fat/non-fat solids ratio & 37 \\
\hline
\end{tabular}

Source: Own calculations.

The support of the milk price by supporting SMP and butter prices is done indirectly because milk is itself a perishable and non-storable product, which gets its value from derived dairy products. Typically, the intervention scheme allows the European Commission to buy in 109,000 tonnes of SMP and 60,000 tonnes of butter between 1 March and 30 September each year, at set prices of $€ 1,698 /$ tonne and $€ 2,217 /$ tonne respectively. After the volume limit is reached, the product can be offered into intervention through a tendering process if proposed by the Commission. The Commission changed the buying-in ceiling for SMP, reducing it to zero for the 2018 window (1 March -

31 September), which may avoid further stock accumulation beyond the 2017 level. Figure 3.1 shows how public stocks levels for SMP and butter have varied over time.

\footnotetext{
3 IMPE stands for Intervention Milk Price Equivalent: the price a processor of commodity products for intervention can afford to pay for the milk. Note that our calculation may be different from that of DGAgri, but this is not expected to affect in any way the arguments made in the main text.
} 


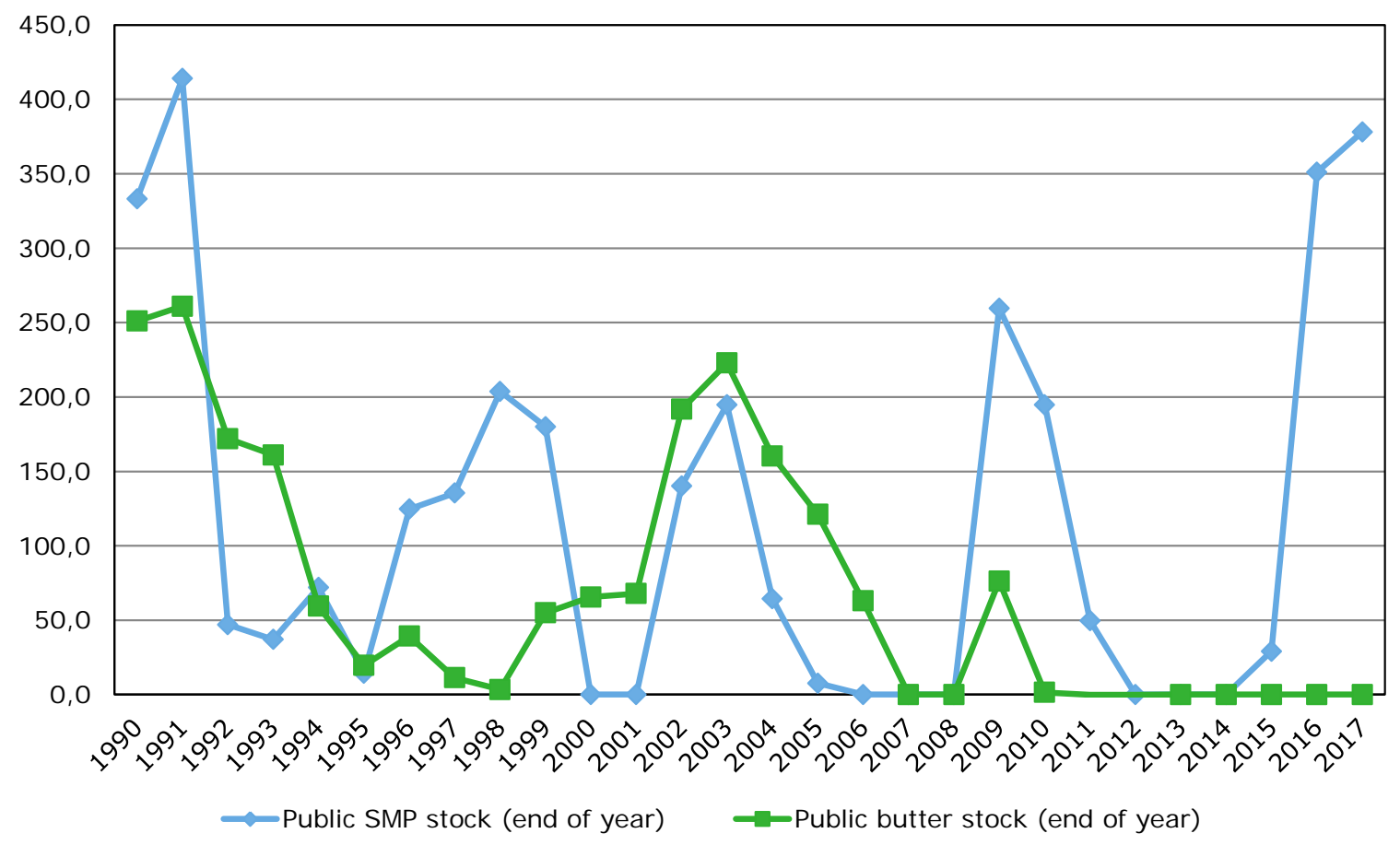

Figure 3.1 EU-28 public intervention stocks of SMP and butter, 1990-2017 (thousand tonnes)

The odd thing about the recent SMP intervention purchases is that stocks were accumulated, mainly because of the low SMP prices, but not because of a very low farm-gate milk price. Due to the strange relative prices in 2017, with a peaking butter price, the milk price was above its safety net level.

Where the latter (supporting the farm-gate milk price) is the primary aim of EU intervention, it should actually use a double-trigger mechanism, and only start considering intervention in the SMP or butter market if the (equivalent) farm-gate milk price has declined below its pre-specified safety net level.

To release SMP intervention stocks to the market, the European Commission opens sales by a tendering procedure of skimmed milk powder (SMP) out of public intervention stocks. As only licenced EU traders can buy SMP from intervention, countries outside the EU are excluded from the tender. The market impacts of stock release are for that reason expected to be first felt in the EU market, and only indirectly have an effect on third country markets.

\subsection{World SMP market}

The world's production of SMP is about $5.7 \mathrm{~m}$ tonnes per annum. The EU produces about $1.55 \mathrm{~m}$ tonnes of this (about 25\%), with other major competitors such as New Zealand, Australia and the US having a share in the world's production of about 33\% (see Table 3.2).

Main importing countries are China, Algeria, Mexico and Russia, which together have a share of about $16 \%$ (similar to the share of the major exporters in world consumption) (Table 3.3). The EU's share in world consumption is about $20 \%$. In volume, the rest of the world is the largest importer (with a share of about $52 \%$ ), but these imports are spread over a large range of countries. 
Table 3.2 Competing exporters of SMP (1,000 tonnes, normalised, based on 2015-16-17 averages)

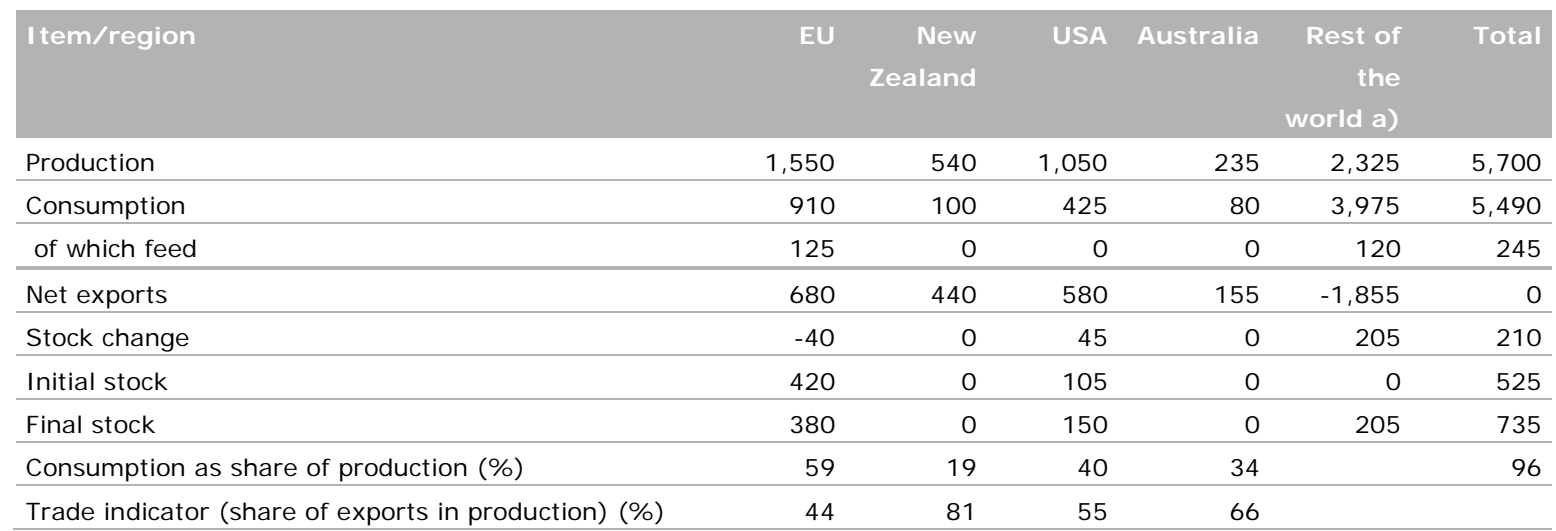

a) Includes statistical differences.

Table 3.3 Major importers of SMP (normalised, based on 2015-16-17 averages)

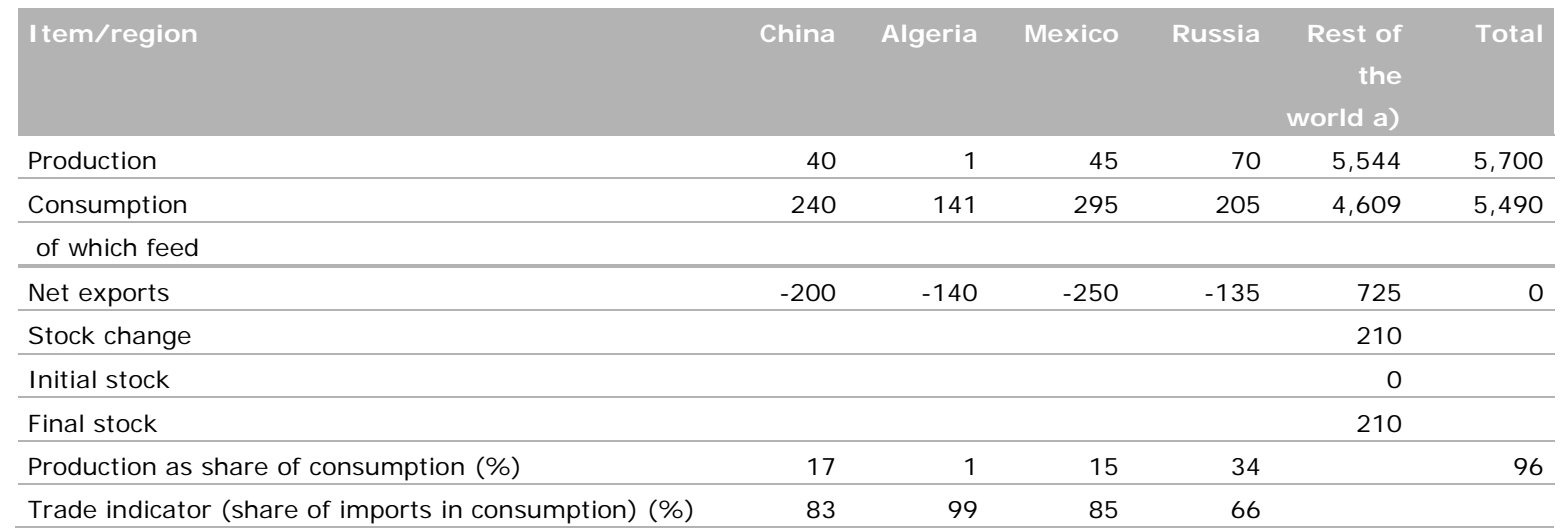

a) Includes statistical differences.

The average market price of SMP in the EU was $144 \mathrm{EUR} / 100 \mathrm{~kg}$ in January 2018, which is below the Intervention Price of 169.8 EUR/ $100 \mathrm{~kg}$. Since 2015 also the US and Oceania have been experiencing relatively low SMP prices (Figure 3.2 ). 


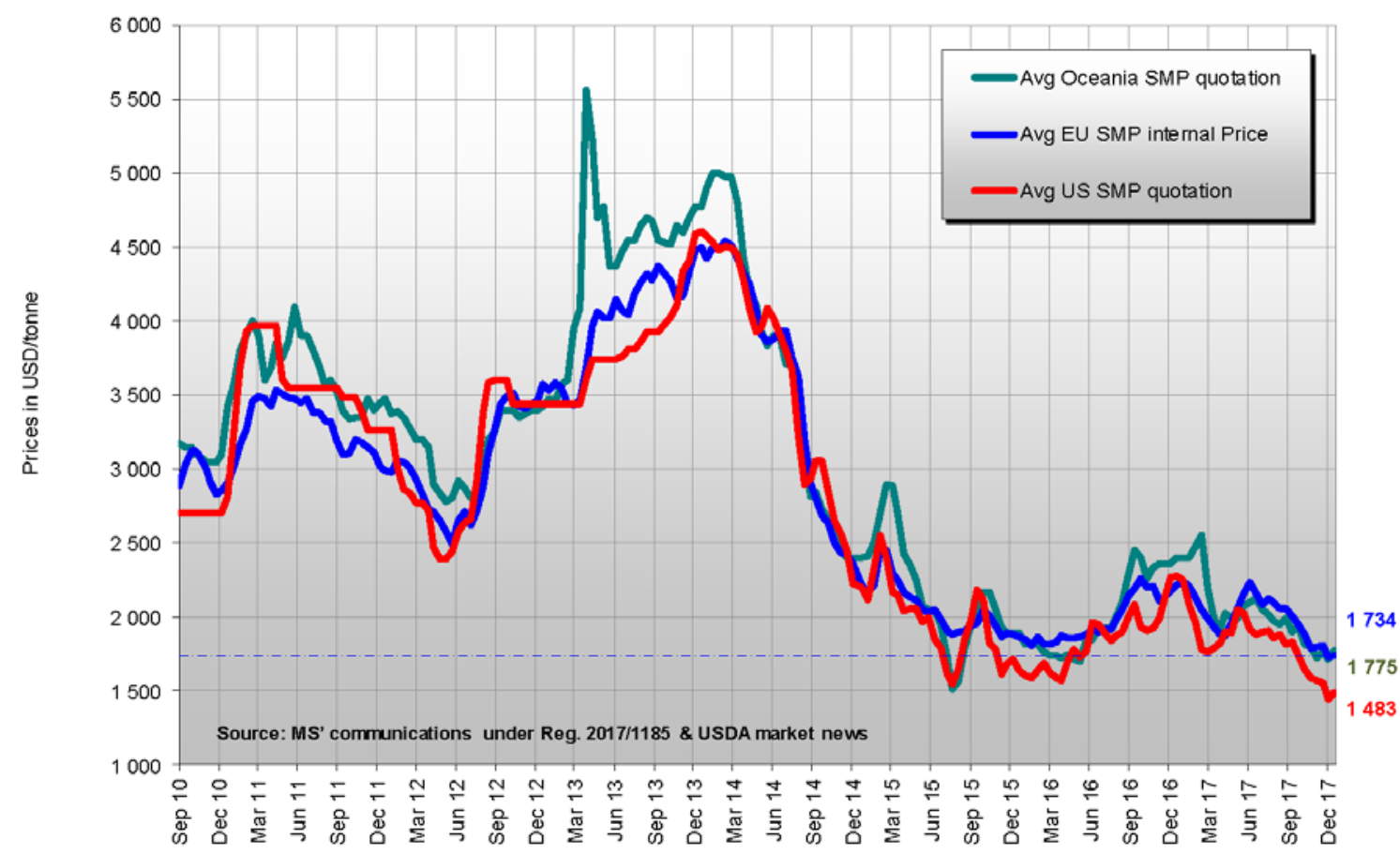

Figure 3.2 EU/US/Oceania Quotations of SMP

Source: European Commission.

Since January 2018 the SMP price has further declined to approximately $€ 135 / 100 \mathrm{~kg}$. At the same time, the butter price is about $€ 400 / 100 \mathrm{~kg}$. Table 3.2 calculates the equivalent milk price (IMPE) using these prices and also provides the value shares of both milk solid components. Note that the IMPE at the market price of $€ 26.62 / 100 \mathrm{~kg}$ is about $27 \%$ above the safety net support price of $€ 21 / 100 \mathrm{~kg}$ (see Table 3.1). The milk fat solids component (butter) counts for more than $60 \%$ of the value of the calculated IMPE.

Table 3.4 Estimated milk price equivalent for March 2018

\begin{tabular}{lrr} 
(values in $€ / 100 \mathrm{~kg}$ ) & SMP & Butter \\
Market price & 135,00 & 400,00 \\
\hline Buying in price & 135,00 & 400,00 \\
\hline less Processing margin & 24,00 & 25,57 \\
\hline Raw material value of product & 111,00 & 374,43 \\
\hline divided by Yield factor (kg. of 3.7\% fat milk / 1 kg of product) & 11,00 & 22,65 \\
\hline IMPE whole milk, 3.7\% fat, delivered & 26,62 & 62 \\
\hline Fat / non-fat solids ratio & 38 & 6 \\
\hline
\end{tabular}

Source: Own calculations. 


\section{$4 \quad$ Different scenarios of selling public intervention stocks of SMP}

\subsection{Destocking strategies}

The recent intervention of SMP took place in the period 2015-2017 and has led to a stock of 378 thousand tonnes. For the analysis, four destocking strategies are analysed that differ with respect to the market outlets (human consumption, non-human use):

1. A fixed sales pattern of monthly sales of 20 thousand tonnes during a period of 1.5 years, aimed at fully depleting current stocks.

2. A sales for non-human consumption strategy; this implies denaturation of the SMP so that it is no longer suitable for human consumption and that it will be sold as a protein source for feed consumption.

3. A mixed sales strategy, where the SMP stock is split up into two categories, taking into account the shelf life. The first category may be sold as high quality product (age less than 1.5 year), whereas the second category has a lower market attractiveness (age more than 1.5 year), which will need a price discount.

4. Sales by a tendering system, where there are separate tenders for stocks by month of intake (period 1 March 2015 - 31 September 2017). This strategy allows taking into account the age impact of the product.

As regards scenario 3, it was initially intended to use the age of 1 year as a criterion to split up the SMP stock into two categories. However, as more than $80 \%$ of the current public SMP stock has been bought in in 2016, a criterion of 1.5 years has been used, assuming that this would allow the splitting of the SMP stock into two equal parts (two halves).

In order to minimise market distortion-effects of the destocking strategies, all strategies include a pattern of fixed periodical (monthly) sales. Although only annual and not monthly periods are modelled, following such a strategy of fixed and steady deliveries will be important (see for a further discussion the next section). These scenarios were translated into categories that could be operationalised in the EDM modelling framework as this was described above (Table 4.1).

Table 4.1 Operationalisation of four EU public SMP stock-release scenarios in EDM framework

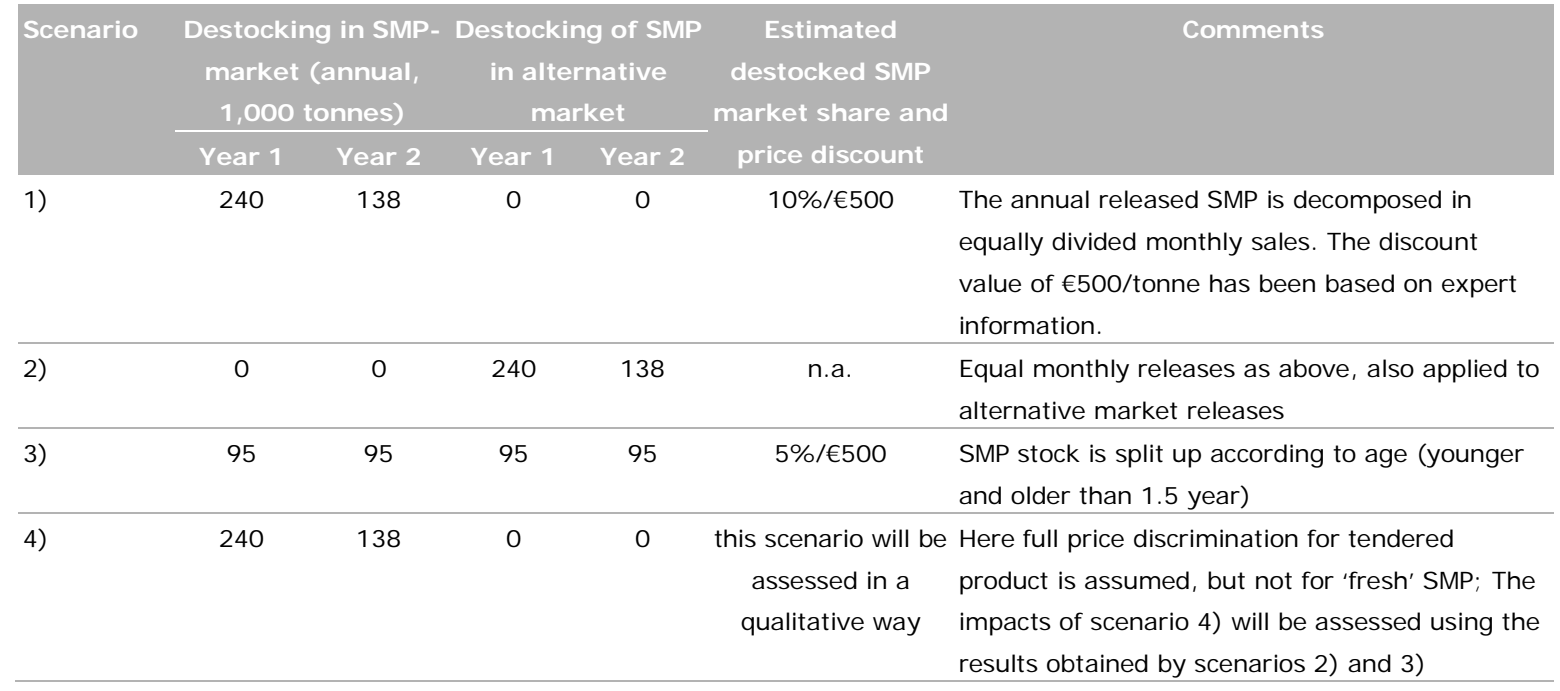

n.a. : not applicable.

Source: Author. 
Scenario 4 can only be analysed when one would know the demand curve for stocked SMP differentiated by age. Unfortunately, it was not possible to get reliable information on this, while there is little evidence from past experiences which is of help. For that reason scenario 4 will only be analysed in a qualitative way.

\subsection{Alternative outlets}

Some scenarios discussed above, notably scenarios 2), 3), and also 4), include making use of alternative market outlets for SMP. Regarding potential alternative outlets for SMP three options have been considered:

A. the use of SMP as input in (vegetable) fat filled powders, used for human consumption;

B. the outlet as feed for the veal sectors (competing or complementing the current use of milk replacer); and

C. the use as a protein source in generic animal feeds.

Ad A. The use of SMP as an input to make fat-filled milk powders (FFMPs) that are then used for human consumption is one of the potential 'alternative' uses. ${ }^{4}$ In 2017 already an increase of EU exports of FFMP has been observed (total SMP exports to ACP countries increased by $26 \%$ as compared to 2016). Though production of fat-filled powders is already an existing practice, it is unclear what further growth potential this could offer. Making fat-filled powders of stocked SMP would imply that the SMP would have to be dissolved in water, after which the fat can be added and spray drying should follow (with the double spray drying of the powder affecting its properties, among which caramelisation). It has been assumed that at EU level the fat-filled powders option could generate an SMP outlet (outlet A) of an additional 20 thousand tonnes per year (which is about 3\% of the EU's 2017 exports to ACP countries). The additional costs of making fat-filled powders based on stocked SMP are estimated to be about $€ 300 /$ tonne. It has been assumed that this is feasible when SMP prices in the range of $€ 1,050$ to 800 would be accepted by the public intervention authorities. ${ }^{5}$

Ad B. The Dutch dairy cow herd is currently close to $1.7 \mathrm{~m}$ heads. Assuming cows give birth to a calve each 13 months, this herd produces about $1.5 \mathrm{~m}$ calves. During at least a 14-day period these calves will stay at the farm (during 2 to 3 days these calves will get colostrum). Part of this calve stock (about 500 thousand) will be used as calves for herd replacement and will usually stay on the dairy farms. They will get about $0.8 \mathrm{~kg} /$ day or $50 \mathrm{~kg}$ in the first 8 to 9 weeks of their growing period. The potential sales would then be 25 thousand tonnes of milk powder, though currently already some SMP is used in these feeds (estimated SMP share is $10 \%$ ). The remainder will leave the farm after about 14 days. They are likely to be fed at a somewhat lower rate $(0.75 \mathrm{~kg} / \mathrm{calve} /$ day $)$, which would create a milk feed demand of 11,250 tonnes. The potential of SMP use is 36.25 thousand tonnes. Milk powders for calves in the upper feed quality segments contain up to 50\% SMP. Using this rate and accounting for the current use of SMP that already takes place, a potential of 18,125 tonnes seems potentially feasible.

As regards the veal meat production in 2017 the number of veal calves used for white meat production in the Netherlands are about 600 thousand. Assuming a weight growth of 50 to $225 \mathrm{~kg}$, a feed conversion $1.45 \mathrm{~kg}$ milk replacer/ $\mathrm{kg}$ of veal meat, and 1.8 production rounds per year (calves go to slaughter at an age of 6 months), the amount of feed needed is 265 thousand tonnes. If a share of SMP of $50 \%$ is assumed, the amount of SMP outlet would be 133 thousand tonnes. The number of calves kept for 'rose meat' is about 360 thousand. Those calves use about $30 \mathrm{~kg}$ of milk or milk replacer per calf. They will be slaughtered at an age of 8 to 10 months. Assuming 1.3 production rounds a year and a 50\% share of SMP, the outlet for SMP would amount 7 thousand tonnes. The thus calculated aggregate outlet of SMP for the Dutch market would be about $158(=18+133+7)$ thousand tonnes. Given that in the EU the dairy herd is currently $23 \mathrm{~m}$ heads and using the Dutch ratios at the

\footnotetext{
4 FFMPs are a mix between dairy proteins and vegetable fat (usually cheap palm oil) with a protein content around $25 \%$. The EU is the major global producer of FFMPs, accounting for almost two-thirds of world production. EU production of FFMPs competes with exports by Malaysia, which is the world's second supplier (EPA Monitoring, 2018).

5 For the SMP price at the moment of the writing of this text a value of $€ 1,350 /$ tonne has been assumed (see also Table 4.2 below).
} 
dairy farms, about 240 thousand tonnes of SMP could be placed. Given that the EU currently produces $4.4 \mathrm{~m}$ tonnes of veal meat (of which $1.4 \mathrm{~m}$ tonnes is produced by the Netherlands) and using this ratio, an additional 450 thousand tonnes of SMP could be placed. It should be noted that this estimate is very rough and probably too high as it does not account for the structural differences between the Dutch veal sector and those in other EU member states. It is assumed that the potential EU SMP use on dairy farms (outlet B1) will be 120 thousand tonnes $(=50 \% * 240)$ and the use in the veal sector (outlet B2) 125 thousand tonnes $(=25 \% * 450)$.

Ad C. SMP could be used as a protein source for generic animal feeds (outlet C), where it then has to compete with other protein sources such as soymeal. The potential demand is then large as the total demand for protein feeds in the EU amounts $27 \mathrm{~m}$ tonnes, with the EU having a degree of selfsufficiency of about $60 \%$ (own calculations based on FEFAC data). It is estimated that at a price of $€ 300 /$ tonne a large amount of SMP could be placed (see Appendix 1 for detailed data on the feed protein market in the EU).

Table 4.2 provides a specification of the assumptions made with respect to the alternative markets, such as entry and exit level prices, as well as maximum sales volumes per category. The estimation of the price levels has been based on expert opinion, but is uncertain since only a few experts in the Netherlands were consulted and their opinions differed. The elasticities are arc elasticities based on the derived average quantity price responses.

Table 4.2 Specification of alternative market outlets for SMP

$\begin{array}{lrrr}\text { Alternative SMP market } & \begin{array}{l}\text { estimated } \\ \text { volume } \\ (1,000 \text { tonnes) } \\ \text { pestination (ranked according to order }\end{array} & \begin{array}{l}\text { entry point } \\ \text { reservation }\end{array} & \begin{array}{l}\text { minimum } \\ \text { reservation } \\ \text { (exit) }\end{array} \\ \text { price a) }\end{array}$

a) The entry point reservation price indicates the price level at which the uptake starts and the minimum (exit) reservation price indicates at what level the indicated volume will be taken up by the indicated market outlet.

Source: Author, based on expert estimates. 


\section{$5 \quad$ Market impacts and budgetary effects}

\section{$5.1 \quad$ Results}

The main results of the scenario simulations are presented in Table 5.1. The impacts have been calculated using the EDM model, as described above. This model has been calibrated to the SMP price level as this prevailed in the first months of 2018 (estimated to be $€ 1,350 /$ tonne).

Table 5.1 Simulation results of EU destocking scenarios on SMP and other markets and budget costs

\begin{tabular}{|c|c|c|c|c|c|}
\hline \multirow[t]{3}{*}{ Scenario } & \multicolumn{2}{|c|}{ Price in SMP market (EU) ( $€ /$ tonne) } & \multirow{3}{*}{$\begin{array}{c}\text { Sales revenue } \\
\text { (million } € \text { ) }\end{array}$} & \multirow{3}{*}{$\begin{array}{c}\text { Budget costs } \\
\text { (million } € \text { ) }\end{array}$} & \multirow{3}{*}{$\begin{array}{c}\text { Release to other } \\
\text { markets } \\
\text { (thousand tonnes) }\end{array}$} \\
\hline & Year 1 & Year 2 & & & \\
\hline & & & & & \\
\hline 2) & $1,347.85$ & $1,347.85$ & 205.16 & 431.47 & 378.00 \\
\hline 3) & $1,317.72$ & $1,317.72$ & 382.44 & 254.24 & 190.00 \\
\hline
\end{tabular}

Source: Own calculations.

Figure 5.1 shows the market price impact of the different EU destocking scenarios (as deviation of the baseline value) for the different regions. ${ }^{6}$ Differences in price impacts between regions relate to different price transmission elasticities between regional markets.

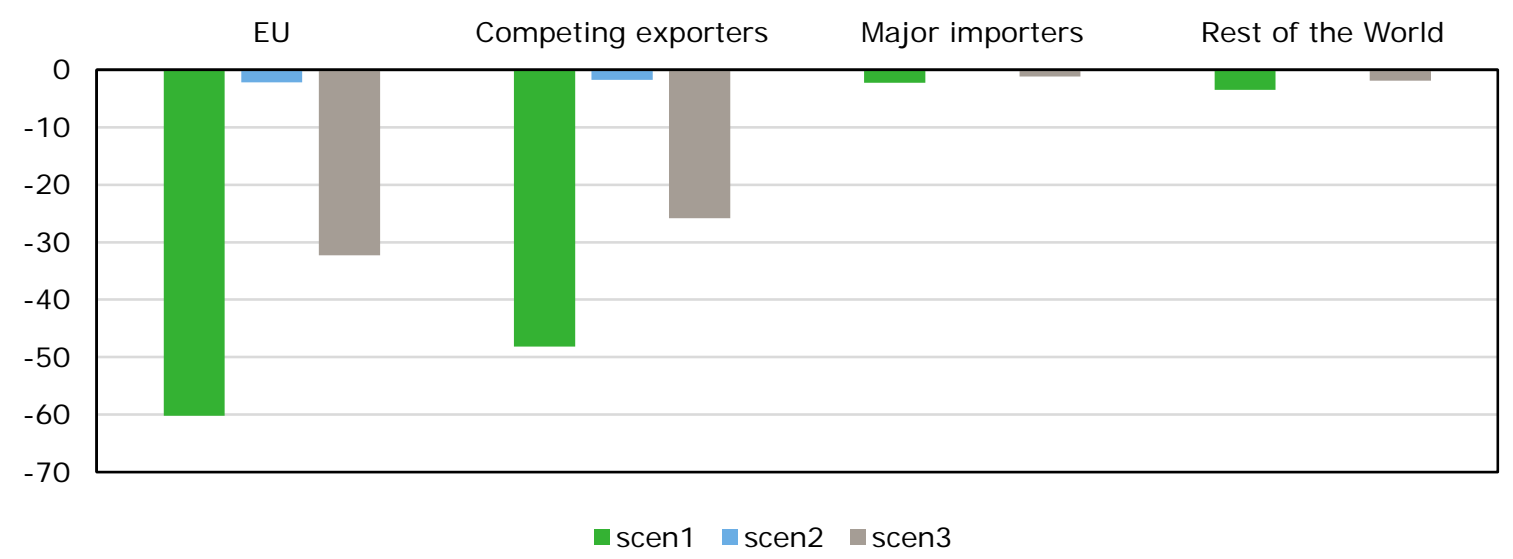

Figure 5.1 Impact on SMP price (changes in $€$ /tonne) of different destocking strategies

\footnotetext{
6 It should be noted that the reported prices are the calculated equilibrium prices (i.e. the prices at the margin). So for scenarios 2 and 3 they represent the equilibrium point of the marginal alternative market outlet and the supply (predetermined stock release). So it has not been assumed that the EU, which acts as a monopoly supplier of stocked SMP, will be able to make use of price discrimination. To the extent this might be possible (i.e. by using an appropriately structured tender procedure), the revenue obtained from SMP stock sales may be higher than the amounts reported here. In that sense the sales revenues numbers in Table 5.1 may be interpreted as lower bounds.
} 


\subsection{Implications}

Quantitative analysis

The outcomes of three destocking scenarios show that they can be ranked differently in terms of the market effects and their budgetary consequences. In scenario 1 prices of SMP decrease by $5.3 \%$ and $3.6 \%$ in 2018 and 2019 respectively. In scenario 3 the market price decline is $-2.4 \%$ for each year. Scenario 2, which involves channelling the destocked SMP fully to alternative markets leads to a marginal negative impact, due to a substitution or spill-over effect from the alternative market to the regular SMP market. The revenues from stock sales are highest in scenario 1 because selling (part of) SMP stocks at alternative markets always yields a lower revenue per tonne of destocked SMP than selling it at the regular market (even when taking into account a $€ 500 /$ tonne discount effect because of perceived lower or deteriorated quality). The prices made at alternative markets vary from $€ 1,000$ to about $€ 495$ per tonne (with prices varying by outlet and due to the quantity sold on the alternative market outlets).

Figure 5.1 provides a more detailed insight into the impact on SMP prices for different scenarios and different regional markets. The strongest price declines are observed in the EU market, and the next largest on the markets of competing exporters. These impacts follow from the assumed price transmission elasticities, which are less than perfect as was indicated by the assessed literature. As a consequence the impact on third country markets is less strong than in the EU. However, as the 'Major importers' and 'Rest of the World' are the main demanding regions, in scenario 1 the EU's destocking strategy is likely to lead to a more intensive competition between the world's key SMP exporters than is the case in scenario 2 (no impact) and scenario 3 (more limited impact).

The budget expenditure differs over scenarios, with scenario 1 having the lowest budget expenditure ( $€ 150 \mathrm{~m}$, takes into account expenditure of both periods). The expenditures in case of scenario 2 are more than double that of scenario 1. The main contributing factor to the differences in EU budget expenditures are the differences in sales revenues. The storage costs and interest costs (playing a minor role) are more or less fixed over all scenarios because they depend on the historical buying-in pattern, while the destocking strategies all lead to a complete elimination of the stocks in a period of 2 years and all scenarios assume a gradual phasing out of the SMP stocks.

When relating these price changes of SMP with the impact they may have on the calculated equivalent milk price (IMPE), given current market conditions (see Table 3.2), it is very unlikely that under any one of the simulated scenarios the IMPE will end up below the safety net provision level of $€ 21 / 100 \mathrm{~kg}$ (see Table 2.1). When applying an SMP price decline of $€ 6 / 100 \mathrm{~kg}$ (or $€ 60 /$ tonne; see Figure 5.1, scenario $1, \mathrm{EU}$ ) and recalculating the IMPE, an equivalent milk price of $€ 26$ would result (-2\%). It should be noted that the calculated IMPE is still $25 \%$ above the safety net provision level. The limited impact is partly due to the importance of the share of fat solids in determining the IMPE under the current price configuration, as well as the still high butter price level.

Qualitative analysis

As regards scenario 4, this involves a tendering process of SMP stocks by age. From our analysis it was difficult to get consensus information of the uses and the discounts as a function of age. For the feed applications, age is not likely to matter. In case of outlet A, it is a potential factor. However, when SMP of about 1.5 year would be still considered as acceptable for fat-filled powders production, then the market impacts of scenario 4 would most likely turn out to be not different from scenario 3. When on the other hand only SMP aged a year or less would be acceptable for outlet i), the market impacts of scenario 4 would be most likely very similar to that of scenario 2 . This is because in relative terms the composition of the SMP stock includes only a small fraction of powder ages less than one year. The revenue from SMP stock sales of scenario 4 are likely to be different from those of scenarios 2 and 3, as scenario 4 implies a more targeted price discrimination, which may lead to a higher extraction of the rents of the buyers out of the market, leading then to potentially higher sales revenues than in scenarios 2 or 3.

There are also aspects to be considered that could not be modelled, but that were raised by the consulted market and industry experts. First, it was indicated that in case of a non-steady delivery for 
some period, this would hamper take-up by the market because potential users may not be willing to consider to adjust their process/supply chain for SMP that will come incidentally available at unclear amount at unclear moments, in unclear quantities. Some kind of regular availability seems a prerequisite for firms in order for them to be willing to accept certain adjustment costs associated with the use or processing of stocked SMP.

Second, in the analysis no changes in private stocks have been accounted for. However, private stocks may at this stage be low, as buyers and sellers anticipate potential price declines due to a coming destocking policy of the EU. When private actors would increase their stocks to more normal levels this could lead to less negative effects on market prices than the ones that we simulated. Third, only a few experts were consulted and their opinions differed, while some experts may have a bias in their opinion. As a result of this the outcomes of the analysis should be taken cautiously.

Strategic behaviour and private stocks

The economics of information and behavioural economics draw attention issues of signalling, strategic behaviour, and anchoring on prices. ${ }^{7}$ There have been an number tenders to sell stocks, where seller (the EU Commission) has lowered the chosen tender price and a maybe surprising low amount of stock has been sold or be taken up by the market. By stepwise lowering the sales price the seller signals that it is accepting that stocked SMP has to be sold way below the intervention price. The stepwise lowering of the sales price, combined with a declining market take-up, may be explained by buyers waiting to purchase stocks in anticipation of further price declines and cheaper future purchase possibilities. As time runs by they also know that the urgency at the seller's side is increasing because of the ageing of stocks and its associated value loss. The transparency about the EU tendering system (e.g. about the number of bids received, the minimum selling prices chosen and the total amount sold at the tender) can in this respect have a drawback as it may intensify undesired signalling issues.

Another area where strategic behaviour is likely to play a role is with respect to private stocking behaviour. In the analysis no changes in private stocks have been accounted for. However, private stocks may at this stage be low, as buyers and sellers anticipate potential price declines due to a coming destocking policy of the EU. When private actors would increase their stocks to more normal levels this could lead to less negative effects on market prices than the ones that we simulated.

Sensitivity analysis

A sensitivity analysis of the results was done by halving the supply and demand elasticities (from 0.5 to 0.25 ). In case of scenario 1 then the maximum price decline calculated for SMP was $10 \%$. One could think of this an approximation of the upper bound of the negative price effect of a gradual phasing out of EU SMP stocks. When viewed in the context of the large price fluctuations that have been observed in the market a $10 \%$ price impact is still relatively small. This suggests that the price changes currently observed in the SMP market can only to a limited extent be explained by the changes in stock levels (see also outcomes of the regression analysis) but are also driven by other factors, including changes in expectations.

\footnotetext{
7 Signalling is the phenomenon occurring in so-called principal-agent settings with asymmetric information, where one party credibly conveys some information about itself to another party. See Stiglitz (2017) as a recent general reference on information economics and consequences for economic policies.
} 


\section{Discussion and concluding remarks}

The EU's SMP public intervention measure is part of a broader intervention arrangement, including butter. By targeting butter and SMP, both the fat solids and non-fat solids parts of raw milk are covered. Together, the SMP and butter intervention measures are thus aimed at supporting the farmgate milk price. In the post-quota period 2015-2017, a 378 thousand tonne SMP stock has been accumulated. The open market structure implies that for EU public intervention to be effective it has to contribute to raising the world market price level. This can be an expensive (potentially involving large volumes) and difficult task since the SMP world market is subject to multiple shocks in various regions.

An impact assessment has been made of several EU destocking strategies. It has been estimated that a gradual phasing out of the EUs SMP stocks over a two-year period is likely to have a negative impact on the EU'S SMP prices of about 5\% (with a likely upper bound of $10 \%$ ). The use of alternative market outlets reduces the negative price impacts on the regular SMP market, but also implies that a significant loss in sales value of SMP stocks has to be accepted. This could lead to an additional budget expenditure up to $€ 280 \mathrm{~m}$. When the stocked SMP ages, at a certain moment there may be no other option than the use of alternative channels to destock and an increasing budget expenditure will then be unavoidable.

Although there is a considerable uncertainty included in the scenarios (e.g. specification of alternative market outlets), a gradual release of EU stocks, with the market determining to whatever use the released stock will be allocated, is very unlikely to have a strong negative impact on the equivalent milk price (IMPE) and creates no risk that the safety net level $(€ 21 / 100 \mathrm{~kg})$ would be hit.

The SMP price-depressing sentiments observed on the market may be larger than is justified by a potential impact of a future EU destocking strategy. Such fears could be justified in case the EU would not gradually but in a relatively short period phase out its stocks. An uneven stock release could lead to short-term market disturbances that are a manifold of the impacts simulated in this study. The latter suggests that the complete uncertainty about the EU's destocking strategy contributes to negative market sentiments. Clarity, be it only already about some aspects of a future destocking strategy (e.g., a gradual rather than an incidental stock release) could most likely already change these sentiments and contribute to price recovery. An additional issue could be strategic and speculative behaviour of potential buyers of stocked SMP due to signalling issues occurring in the current way the tendering system is organised (a more limited provision of information could maybe reduce this impact).

The recent limit put on SMP intervention does not imply that the safety net condition to the farm-gate milk price is no longer effective. Due to the imbalance in fat solid (highly priced) and non-fat solids prices, with both counteracting each other, the farm-gate milk price safety net has not been at risk.

Where supporting the farm-gate milk price is the primary aim of EU intervention, it is recommended to actually use a double-trigger mechanism, and only start considering intervention in the SMP or butter market if the (equivalent) farm-gate milk price has declined below its pre-specified safety net level.

Given the increased market orientation and given the observed structural change in dairy markets in favour of milk fat rather than protein, the intervention price level as it is currently defined for SMP may need reconsideration and be in need to be lowered. A safety net provision should have two properties: i) be operational only in exceptional cases; and ii) then be robust in its functioning. Addressing this question is beyond the scope of the current study, but should be given further reflection as there can be doubts whether the two requirements are still satisfied. 
It should be noted that this study has several limitations. The quantitative assessment has been made using a simple EDM or partial model, which however covers the world SMP market. The development and calibration of the model to alternative outlets has been made based on descriptive market assessments, informed assumptions based on experts opinions, and generalisations to EU level based on insights obtained from the Dutch veal market situation. Only a few experts were consulted and their opinions differed, while they may have a bias in their opinion. As a result of this, the outcomes of the analysis should be taken cautiously. Given the scope of the research and the limits of time and resources it was tried to address the issues as best as possible, but several uncertainties remain. 


\section{References and websites}

Bartova, L., Fellmann, F., and M'barek, R. (2009). Modelling and analysis of the European milk and dairy market. Seville, European Commission, Joint Research Center, Institute for Prospective Technical Studies.

Carvalho, G.R., Bessler, D., Hemme, T. and Schroer-Merker, E. (2015). Understanding Internal Milk Price Relationships. Paper presented at annual meeting of Southern Agricultural Economics Association. Atlanta, GA. February.

Chavas, J.P. and Kim, K. (2001). Hedonic pricing of component and cointegration relationships: a dynamic analysis of dairy product prices. Food System Research Group, Working paper series FSWP2001-1.

Directorate-General for Agriculture and Rural Development - Short- term Outlook for EU agricultural markets in 2017 and 2018- $N^{\circ} 17$ http://ec.europa.eu/agriculture/markets-andprices/index_en. htm

European Commission, Agricultural Outlook; Prospects for EU agricultural markets and income 20162026; Report. Brussels, DG-AGRI, (December 2016).

European Commission, 2018. Milk Market Situation, 18 January 2018.

Gould, B.W. and Villarreal, H.J . (2002). A Descriptive Analysis of Recent Trends in the International Market for Dry Milk Products. Babcock Institute for International Dairy Research and Development, University of Wisconsin. http://purl.umn.edu/37639.

Newton, J. (2016). Price Transmission in Global Dairy Markets. International Food and Agribusiness Management Review, Special Issue 19(B): 57-72.

OECD/FAO (2016). OECD-FAO Agricultural Outlook 2016-2025, OECD Publishing, Paris. http://dx.doi.org/10.1787/agr_outlook-2016-en

P. Salamon, M. Banse, J. Barreiro-Hurlé, O. Chaloupka, T. Donnellan, E. Erjavec, T. Fellmann, K. Hanrahan, M. Hass, R. Jongeneel, V. Laquai, M. van Leeuwen, A. Molnár, M. Pechrová, G. Salputra, W. Baltussen, J. Efken, S. Hélaine, J. Jungehülsing, O. von Ledebur, I. Rac, F. Santini (2017). Unveiling diversity in agricultural markets projections: from EU to Member States. A medium-term outlook with the AGMEMOD model. JRC Technical Report, 29025 EUR, Publications Office of the European Union, Luxembourg, ISBN 978-92-79-77335-8, doi: 10.2760/363389.

Stiglitz, J.E. (2017). The revolution of information economics: the past and the future. Cambridge, MA, National Bureau of Economic Research, Working paper 23780 


\section{Appendix 1 Feed protein market in the EU}

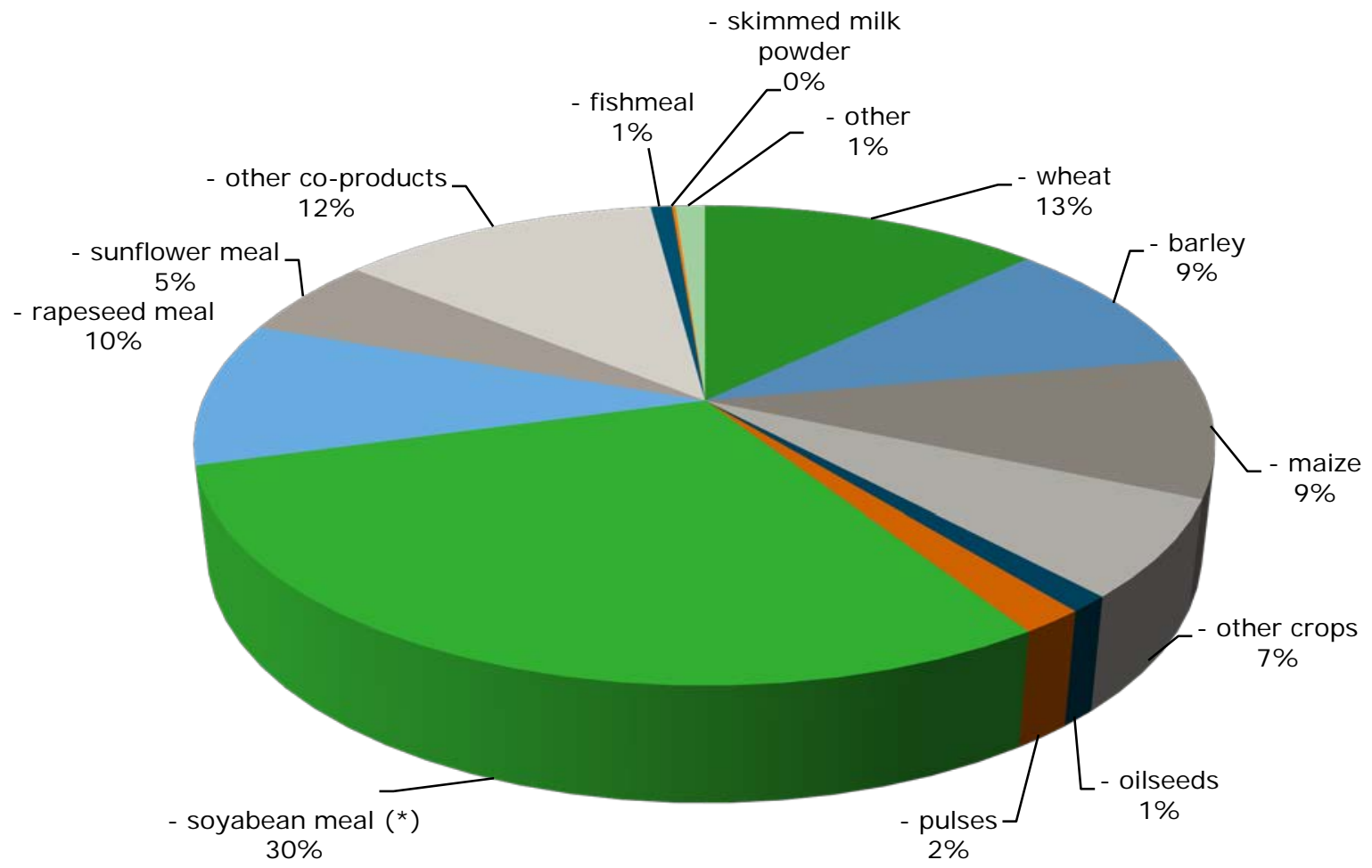

Figure A1.1 Sources of proteins for feed use in EU-28, 2016/17 (expressed in 'equivalent protein', excluding forages) 
Table A1.1 EU production and use of proteins for feed, 2016/17 (expressed in 'equivalent protein', excluding forages)

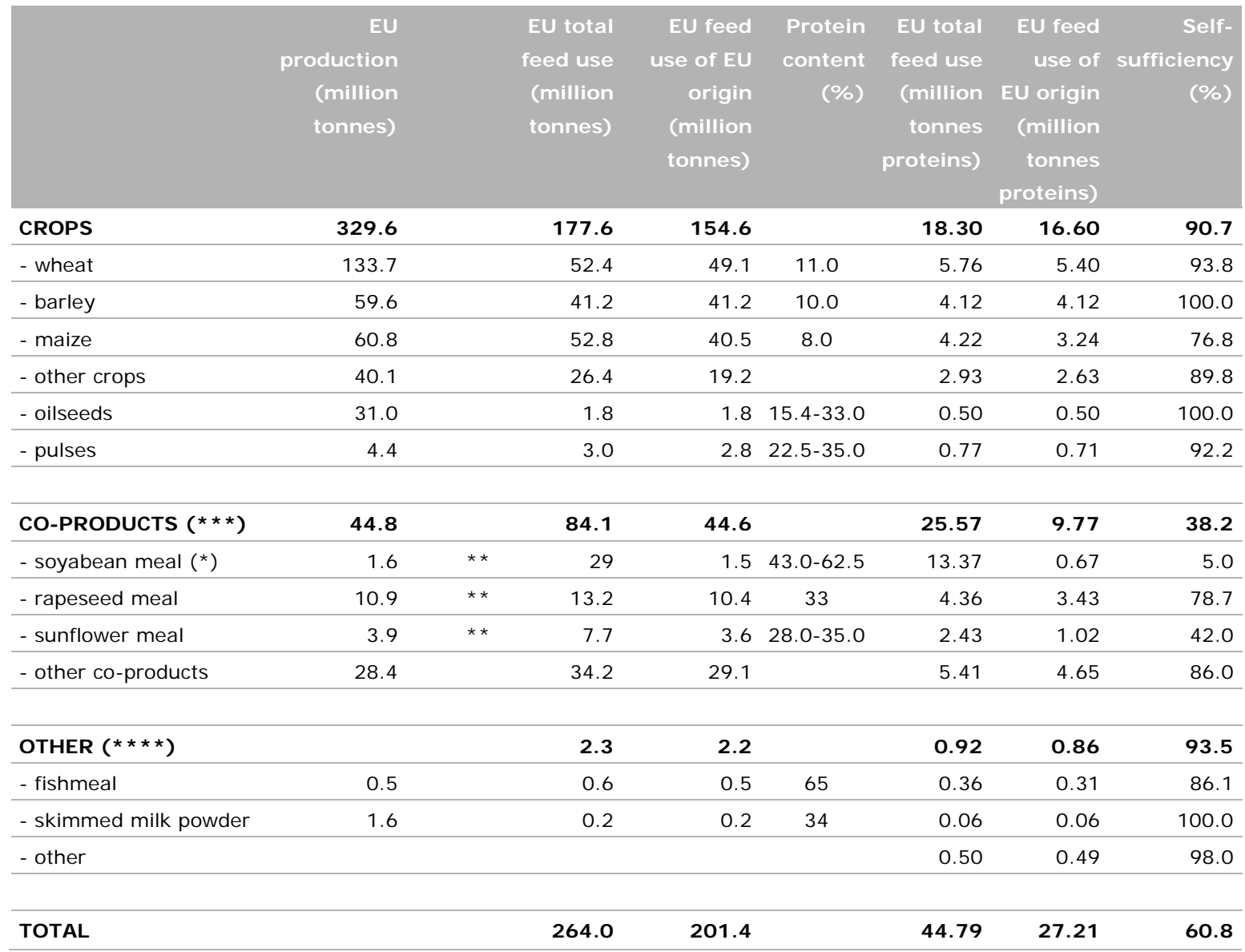

$(*)$ : including soy protein concentrate.

$(* *)$ : from EU produced seeds.

$(* * *)$ : excluding on farm uses for co-products other than soy, rapeseed and sunflower meal

$(* * * *)$ : excluding on farm uses. 
Wageningen Economic Research P.O. Box 29703

2502 LS The Hague

The Netherlands

T +31 (0)70 3358330

E communications.ssg@wur.nl

www.wur. eu/economic-research

Wageningen Economic Research REPORT

2018-046
The mission of Wageningen University \& Research is "To explore the potential of nature to improve the quality of life". Under the banner Wageningen University \& Research, Wageningen University and the specialised research institutes of the Wageningen Research Foundation have joined forces in contributing to finding solutions to important questions in the domain of healthy food and living environment. With its roughly 30 branches, 5, 000 employees and 10,000 students, Wageningen University \& Research is one of the leading organisations in its domain. The unique Wageningen approach lies in its integrated approach to issues and the collaboration between different disciplines. 



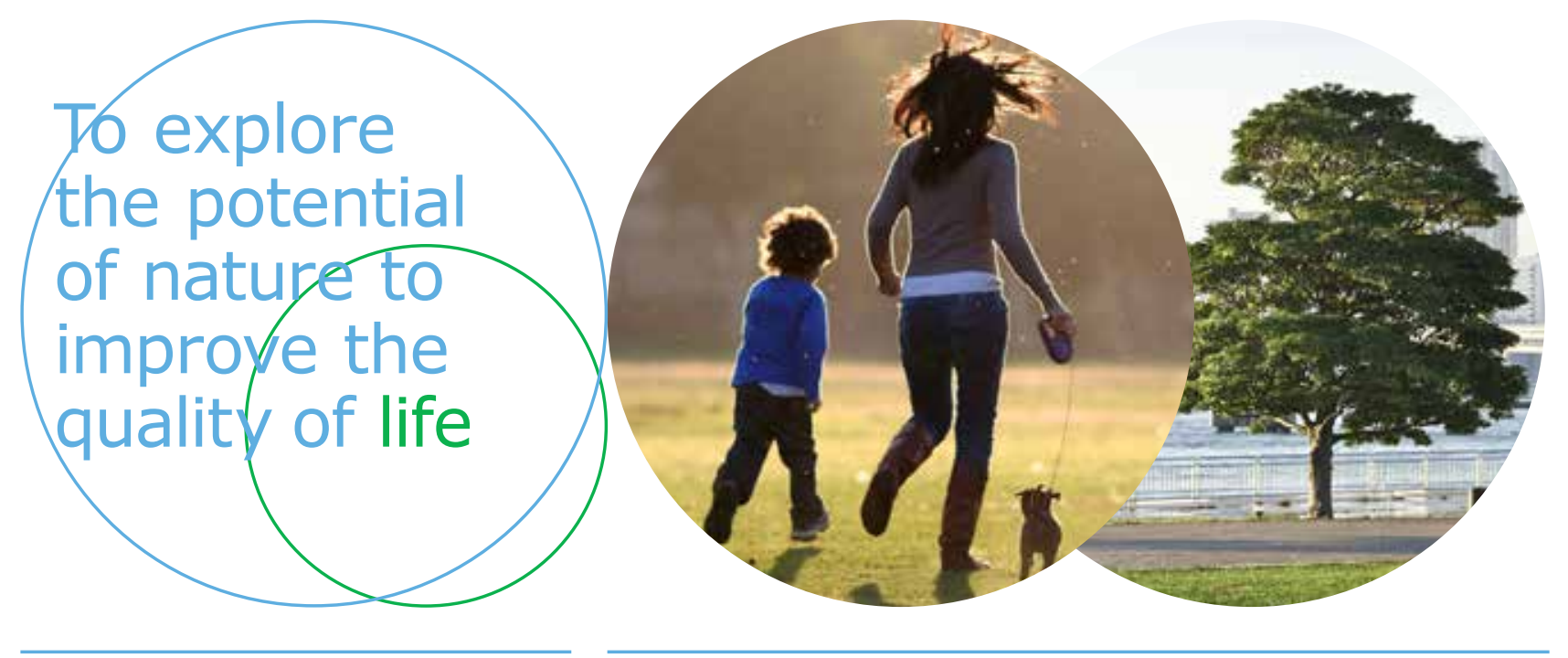

Wageningen Economic Research P.O. Box 29703

2502 LS Den Haag

The Netherlands

E communications.ssg@wur.nl www.wur.eu/economic-research

Report 2018-046

ISBN 978-94-6343-857-5
The mission of Wageningen University \& Research is "To explore the potential of nature to improve the quality of life". Under the banner Wageningen University \& Research, Wageningen University and the specialised research institutes of the Wageningen Research Foundation have joined forces in contributing to finding solutions to important questions in the domain of healthy food and living environment. With its roughly 30 branches, 5,000 employees and 10,000 students, Wageningen University \& Research is one of the leading organisations in its domain. The unique Wageningen approach lies in its integrated approach to issues and the collaboration between different disciplines. 